\title{
Tata Kelola dan Kebijakan Wilayah Konservasi Mangrove Di Kabupaten Bintan
}

\author{
Irman Irman ${ }^{1}$, Dhani Akbar² \\ 1Program Studi Ilmu Hukum, Fakultas Ilmu Sosial dan Ilmu Politik, \\ Universitas Maritim Raja Ali Haji, Kota Tanjungpinang, Provinsi Kepulauan Riau \\ 3Program Studi Ilmu Hubungan Internasional, Fakultas Ilmu Sosial dan Ilmu Politik, \\ Universitas Maritim Raja Ali Haji, Kota Tanjungpinang, Provinsi Kepulauan Riau \\ Corresponding Author: akbardhani@umrah.ac.id
}

Keyword:

Kebijakan; Penegakan hukum; Keberlanjutan Lingkungan;

\begin{abstract}
Mangrove di pulau Bintan, sama halnya yang terjadi di Indonesia, mengalami sejumlah permasalahan umum seperti imbas dari penangkapan ikan, pembangunan pesisir,pencemaran lingkungan, perubahan iklim dan pengasaman laut. Terbitnya Peraturan Presiden Nomor 120/2020 Tahun 2020 menandai pembentukan Badan Restorasi Gambut dan Mangrove atau BRGM oleh Pemerintah Republik Indonesia. Penelitian ini menggunakan metode desktiptip kualitatif, yang mana dijabarkan melalui telaah kebijakan dan hokum lingkungan. Adapun dalam indikator kebijakan, seringkali yang dijumpai dalam model kebijakan Top-Down ataupun Bottom-Up, yang seringkali dilihat adalah goal daripada kebijakan tersebut, namun, dua kelompok penulis penting secara eksplisit menghubungkan variabel ke dalam model, Mazmanian dan Sabatier. Penegakan hukum Nomor 32 Tahun 2009 tentang Perlindungan dan Pengelolaan Lingkungan Hidup, adalah tentang kriteria perbaikan kerusakan ekosistem lingkungan dan perubahan iklim. salah satu dari perlindungan ekosistem mangrove dan Peraturan Daerah (PERDA) No. 14/2007 tentang Ketetanggaan Pulau Bintan dan perencanaan wilayah pesisir. pelestarian mangrove di Bintan, Pemerintah perlu menerapkan Rencana Zonasi Wilayah Pesisir dan Pulau-Pulau Kecil (RZWP3K) dengan peta sinkron, Rencana Peraturan Daerah Provinsi (RAPENDA).
\end{abstract}

\section{PENDAHULUAN}

Ekonomi biru merupakan pemanfaatan berkelanjutan sumber daya laut untuk pertumbuhan ekonomi, meningkatkan mata pencaharian dan pekerjaan, serta kesehatan ekosistem laut. Ekonomi biru mencakup banyak kegiatan mulai dari transportasi laut, perikanan, penggunaan energi terbarukan, pariwisata, hingga perubahan iklim. Pelestarian ekosistem mangrove akan mendukung ekonomi biru global. Kesadaran akan pentingnya menjaga dan melestarikan ekosistem mangrove yang mana juga diperlukan untuk merehabilitasi setiap aktifitas pembangunan dan ekspoitasi wilayah teresterial dan pesisir sedang dalam perkembangan yang pesat, beberapa wilayah diketahui mengalami degradasi akibat aktifitas ini, di antaranya pengaruh abrasi akibat hilangnya ruang terbuka hijau, maka dari itu dipandang sangat perlu dilakukan rehabilitasi pasca aktifitas tersebut dilaksanakan dalam kegiatan ini, guna mengembalikan fungsi ekologis dan kealamian suatu wilayah. Blankespoor, Dasgupta, dan Lange dalam Patil mengatakan bahwa sebuah studi baru-baru ini memperkirakan bahwa di 46 negara yang memiliki lebih dari 53 persen perkiraan hutan bakau di seluruh dunia, ekosistem ini mengurangi luasnya wilayah pesisir yang terkena gelombang badai sekitar 30 persen atau 36.061 kilometer persegi. (Patil et al., 2016). 


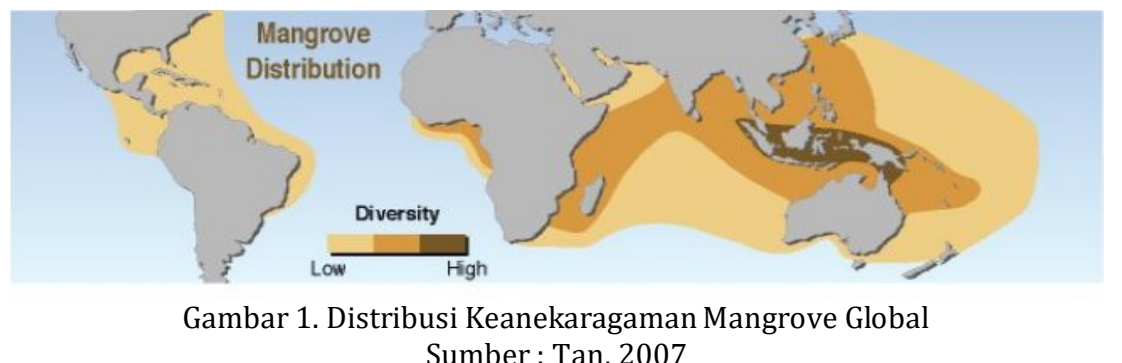

Mangrove secara global memiliki keanekaragaman masing-masing dan di mana pada gambar 1 menunjukkan di Indonesia memiliki tingkat keanekaragaman yang sangat tinggi. Kekhasan Mangrove yang unik membentuk satu ekosistem yang terdapat di daerah pasang surut wilayah pesisir ini diyakini mampu memberikan kontribusi penting terhadap lingkungan sekitar. 637.624 dari 3,31 juta hektar lahan mangrove di Indonesia berada dalam kondisi kritis. Kelestarian ekosistem mangrove merupakan salah satu penentu kesehatan ekosistem pesisir dan tentunya berkaitan dengan sumber ekonomi bagi masyarakat pesisir karena mangrove mendukung kegiatan sektor perikanan, budidaya dan pemanfaatan pariwisata. Terbitnya Peraturan Presiden Nomor 120/2020 Tahun 2020 menandai pembentukan Badan Restorasi Gambut dan Mangrove atau BRGM oleh Pemerintah Republik Indonesia. BRGM menjadi produk kebijakan kontinu Pemerintah di mana berasal dari Badan Restorasi Gambut/ BRG sejak 2016 hingga akhir tahun 2020. Secara harafiah, BRGM memiliki mandate yang mencakup rehabilitasi mangrove/ bakau seluas 600.000 ha yang ditargetkan di akhir tahun 2024 yang mencakup sembilan propinsi prioritas, di antaranya Sumatera Utara, Riau, Kepulauan Riau, Bangka Belitung, Kalimantan Barat, Kalimantan Timur, Kalimantan Utara, Papua, dan Papua Barat.

Mangrove di pulau Bintan, sama halnya yang terjadi di Indonesia, mengalami sejumlah permasalahan umum seperti imbas dari penangkapan ikan sebab kisaran 29\% overfished dilakukan di seluruh dunia. Dalam perhitungan, sekitar 11 hingga 25 juta ton ikan ditangkap melalui illegal, unreported and unregulated (IUU) fishing setiap tahun (Agnew et al., 2008) dan juga kegiatan tambak yang banyak dieksploitasi secara ekstensif, dan benih udang biasanya diperoleh dari kawasan bakau yang berdekatan. Dalam banyak kasus, pembangunan tambak dilakukan untuk mendapatkan sertifikat tanah di wilayah yang sebelumnya dikuasai secara komunal, atau wilayah tanah pemerintah. (Giesen et al., 2006). Selain itu, pembangunan pesisir seperti pengisian lahan atau garis pantai yang mengeras karena konstruksi, signifikan mengubah ekosistem dan ekosistem proses. Kemudian pencemaran, di mana sebagian besar dalam bentuk limbah yang tidak diolah, yang meningkat secara kasar tiga kali lipat dari tingkat pra-industri (UNEP 2012b) untuk menciptakan 245.000 kilometer persegi laut pada tahun 2010, bersama dengan perkiraan 4,8 hingga 12,7 juta ton plastik memasuki lautan setiap tahun (Jambeck et al. 2015).

Selain itu, dampak tumpahan minyak di laut mengancam ekosistem laut di perairan Kepulauan Riau dan juga mengancam mata pencaharian Masyarakat Bintan khususnya nelayan. Limbah minyak juga mengancam sektor pariwisata Provinsi Kepulauan Riau yang bertumpu pada wisata bahari. Dengan kata lain, minyak tumpahan berdampak serius tidak hanya pada ekosistem laut tetapi juga warga Kepulauan Riau yang mengandalkan perikanan dan pariwisata sebagai sumber mata pencaharian. (Dhani Akbar et al., 2020); dan terakhir, perubahan iklim dan pengasaman laut, termasuk permukaan yang lebih tinggi suhu air dan naiknya permukaan laut, bersama dengan lebih asam perairan karena penyerapan karbon dioksida dari atmosfer - dengan rata-rata $\mathrm{pH}$ 
permukaan laut sudah menurun dari 8,2 menjadi 8,1 dan diproyeksikan akan berlanjut menjadi 7,7 atau 7,8 pada tahun 2100 (UNEP, 2012b) (Patil et al., 2016).

Pengembangan ekonomi lokal menjadi inti dari kegiatan desain restorasi mangrove melalui pendekatan padat karya, sepanjang tahun 2021, kegiatan penanaman mangrove di sembilan provinsi diperkirakan melibatkan 203.500 tenaga kerja lokal. Dengan alokasi Rp. 1,5 miliar, dan lebih dari 50\% akan dihabiskan untuk aktifitas pembibitan dan penanaman yang dilakukan oleh pekerja lokal dari desa masing-masing. Dalam target indikatif rehabilitasi mangrove tahun 2021-2024 untuk Provinsi Kepulauan Riau dengan total luas mangrove kritis $37.432 \mathrm{Ha}$. Rencana percepatan rehabilitasi mangrove tahun 2021 dengan skema perencanaan meliputi target lokasi, desain teknis, kelembagaan pelaksana, mekanisme pelaksana, penyiapan dan penyediaan bibit, penanaman, pembinaan dan monitoring evaluasi serta pelaporan agar pelaksanaan kegiatan efektif sesuai dengan target-target yang diharapkan.

Karakteristik Pulau Bintan yang sebagian besar memiliki zona intertidal yang pendek, saat partikel tanah atau sedimen dari lahan kritis yang menyebabkan kematian pada habitat mangrove dan sekitarnya. Kawasan Konservasi Perairan adalah kawasan perairan yang dilindungi, dikelola dengan sistem zonasi, untuk mewujudkan pengelolaan sumber daya ikan dan lingkungannya secara berkelanjutan di mana Rehabilitasi dilakukan untuk memulihkan, memperbaiki, meningkatkan kondisi lahan agar berfungsi kembali secara optimal. (Yudiatmaja et al., 2020) Mangrove di kawasan Bintan memang tidak mengalami ancaman seperti program reklamasi dan sejenisnya seperti yang diungkapkan oleh Setijawati, yang tentu pada akhirnya akan berpengaruh terhadap keberlangsungan keanekaragaman hayati di sekitar mangrove itu sendiri. (2017: 228).

Adapun dikutip dari Yayasan Ecology, struktural menekankan pengaruh struktur masyarakat dan lingkungan pada seperangkat norma, nilai, ide, dan praktik umat manusia. Di sisi lain, Lensa fungsional memandang modal sosial sebagai konsekuensi dari sistem sosial. Rencana Pengelolaan Kawasan Konservasi Perairan adalah dokumen kerja yang dapat dimutakhirkan secara periodik, sebagai panduan operasional pengelolaan kawasan konservasi perairan. Zona kawasan konservasi perairan dilakukan penataan berdasarkan fungsi dengan mempertimbangkan potensi sumber daya, daya dukung, dan proses-proses ekologis, seperti yang terdapat pada gambar di bawah ini.

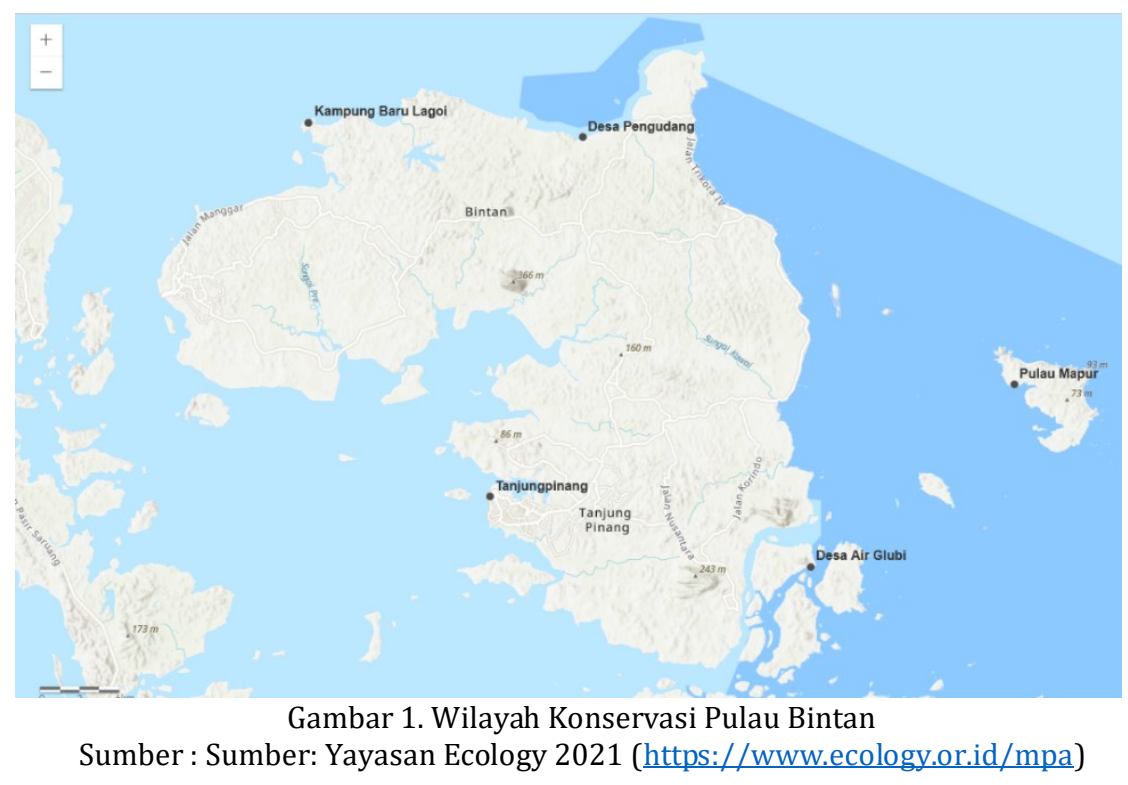


Keberadaan kawasan konservasi sudah semestinya dapat memberikan dampak positif terhadap keberlangsungan sumberdaya dan peningkatan kesejahteraan masyarakat di sekitaranya, dari data produksi perikanan tangkap Kabupaten Bintan (2014-2018), terlihat bahwa produksi sumberdaya ikan meningkat. Namun seiring dengan adanya perencanaan pengelolaan zonasi di kawasan konservasi Bintan pada tahun 2019 dimulai dengan meninjau kembali (review) dokumen Rencana Pengelolaan dan Zonasi KKPD Bintan, semestinya konservasi di lapangan memiliki imbas yang lebih besar.

\section{METODE PENELITIAN}

Penelitian ini menggunakan metode desktiptip kualitatif, yang mana dijabarkan melalui telaah kebijakan dan hokum lingkungan. Adapun dalam indikator kebijakan, seringkali yang dijumpai dalam model kebijakan Top-Down ataupun Bottom-Up, yang seringkali dilihat adalah goal daripada kebijakan tersebut, namun, dua kelompok penulis penting secara eksplisit menghubungkan variabel ke dalam model, Mazmanian dan Sabatier (lihat, misalnya, 1983) dan Van Meter dan Van Horn (dalam Andresen, 1995).

\begin{tabular}{|c|c|c|c|}
\hline \multicolumn{2}{|c|}{ Van Meter dan Van Horn (1975) } & \multicolumn{2}{|c|}{ Mazmanian dan Sabatier (1983) } \\
\hline \multirow{3}{*}{$\begin{array}{l}\text { proses } \\
\text { implementasi } \\
\text { akan } \\
\text { bervariasi } \\
\text { tergantung } \\
\text { pada sifat } \\
\text { kebijakan } \\
\end{array}$} & $\begin{array}{l}\text { a) jumlah perubahan yang } \\
\text { terlibat; }\end{array}$ & \multirow{3}{*}{$\begin{array}{l}\text { kemampuan } \\
\text { mengatasi } \\
\text { masalah }\end{array}$} & $\begin{array}{l}\text { a) kemampuan undang- } \\
\text { undang untuk menyusun }\end{array}$ \\
\hline & \multirow{2}{*}{$\begin{array}{l}\text { b) tingkat konsensus } \\
\text { tujuan di antara para } \\
\text { peserta dalam proses } \\
\text { implementasi. }\end{array}$} & & b) implementasi \\
\hline & & & $\begin{array}{l}\text { c) variabel non-statutory } \\
\text { yang mempengaruhi } \\
\text { implementasi }\end{array}$ \\
\hline Indikator & $\begin{array}{l}\text { a) standar dan tujuan } \\
\text { kebijakan; b) sumber daya; } \\
\text { c) komunikasi antar } \\
\text { organisasi dan kegiatan } \\
\text { penegakan; d) ciri-cirinya } \\
\text { lembaga pelaksana; e) } \\
\text { kondisi ekonomi, sosial } \\
\text { dan politik; f) disposisi dari } \\
\text { pelaksana }\end{array}$ & Indikator & $\begin{array}{l}\text { output kebijakan, } \\
\text { kepatuhan terhadap } \\
\text { kebijakan, actual dampak, } \\
\text { dampak yang dirasakan, } \\
\text { revisi besar dalam } \\
\text { undang-undang }\end{array}$ \\
\hline
\end{tabular}

Dalam telaah politik lingkungan internasional juga seringkali menimbulkan tantangan yang berbeda dari yang lain masalah kurangnya konsensus mengenai apa yang merupakan efektivitas kebijakan bagi banyak peneliti yang bekerja di lapangan. Beberapa melihat negosiasi perjanjian internasional sebagai bukti kerjasama sementara yang lain percaya kepatuhan diperlukan. Tidak seperti kebanyakan daerah lain, Namun, ada perdebatan yang sedang berlangsung di subbidang mengenai apakah kepatuhan adalah objek studi yang tepat, karena kepatuhan bukanlah suatu keharusan atau kondisi yang cukup untuk mencapai apa yang oleh banyak sarjana dianggap sebagai tujuan akhir dari kerjasama lingkungan internasional, yaitu perbaikan lingkungan yang signifikan. (Wolinsky \& Yael, 2020). Adapun objek dari penelitian ini adalah mangrove seperti pada Gambar 3 yang tersebar di seluruh wilayah pulau Bintan, pada daerah-daerah prioritas yang memiliki potensi yang sangat besar terhadap ekowisata dan lingkungan yang berkelanjutan. 


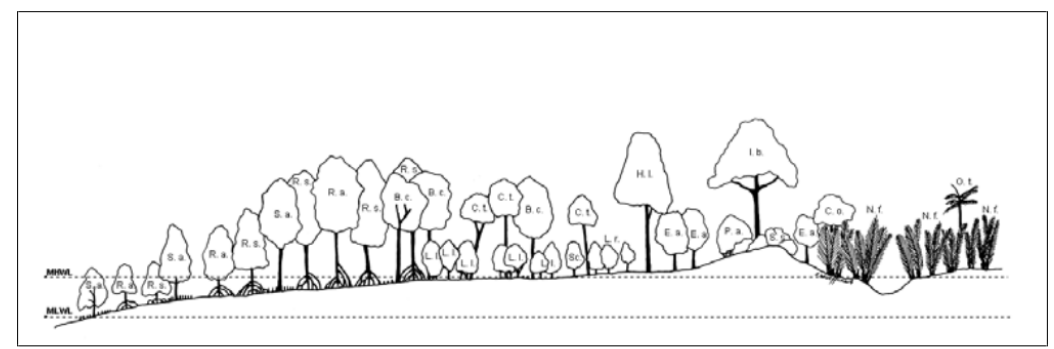

Substrates of frontal area consist of coarse sands, while inland it is mixed with loam \& clay.

B.c. - Bruguiera cylindrica

C.t. - Ceriops tagal

H.1. - Heritiera littoralis

L.1. - Lumnitzera littorea

N.f. - Nypa fruticans

P.a. - Pemphis acidula

R.s. - Rhizophora stylosa

S.a. - Sonneratia alba
C.b. - Cerbera odollam

E.a. - Excoecaria agallocha

I.b. - Intsia bijuga

L.r. - Lumnitzera racemosa

O.t. - Oncosperma tigillarium

R.a. - Rhizophora apiculata

Sc. - Scyphiphora hydrophyllacea

Gambar 3. Schematic Cross-Section Mangrove wilayah pesisir dari Bintan Provinsi Kepulauan Riau. Sumber: Giesen et al., 2006

\section{HASIL DAN PEMBAHASAN}

Kriteria kebijakan yang ditawarkan untuk masalah mangrove, sebenarnya seringkali bersifat dua, top-down atau bottom up, di mana bisa dikategorikan dalam empat indikator, yaitu fakus insial, identifikasi aktor-aktor yang terlibat, kriteria yang evaluatif, dan fokus secara keseluruhan. (Andresen, 1995). Seringkali yang muncul adalah, jika dilakukan secara bottom up, kehadiran dari decision makers masih bermasalah, kesulitan dalam menggunakan dominant policy, seringkali tidak mengena pada sasaran-sasaran dari kebijakan sentral, dan terdapat pembedaan antara formulasi kebijakan dan implementasi yang misleading. Seperti dalam rangka mendukung pelestarian mangrove di Bintan, Pemerintah perlu menerapkan Rencana Zonasi Wilayah Pesisir dan Pulau-Pulau Kecil (RZWP3K) dengan peta sinkron, Rencana Peraturan Daerah Provinsi (RAPENDA), lampiran pengukuran wilayah dan penomoran zona dan penamaan sub-zona situs pariwisata dengan, tentu saja, bersama dengan Konservasi Ekosistem Mangrove dan Pemanfaatan Berkelanjutan di ASEAN (MECS). (Akbar et al., 2021).

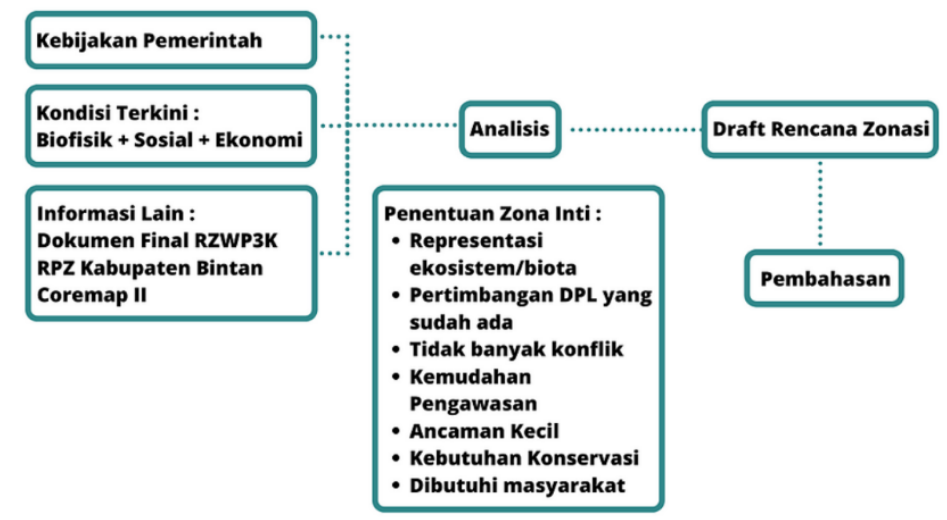

Gambar 4. Pola Kebijakan Zonasi Wilayah Konservasi Bintan Sumber: Yayasan Ecology 2021

Dalam konteks mengulas kebijakan konservasi mangrove, telaah sosial sendiri sebenarnya terdiri dari pencarian tindakan yang saling terkait untuk memuaskan 
identitas dan minat dengan menyesuaikan perilaku untuk berubah insentif di lingkungan. Model konstruktivis mengasumsikan bahwa agen itu sendiri sedang dalam proses ketika mereka berinteraksi. Properti mereka bukan hanya perilaku yang dipertaruhkan. (Ikenberry \& Wendt, 1999).

Jika bersifat top-down, seperti pola yang diterapkan oleh Andersen (Andresen, 1995), maka seringkali yang hadir adalah kesulitan pemberimasukan dari sektor sub nasional ke level yang lebih tinggi, partisipasi tidak berbasis kepada sasaran, namun kepada jejaring yang telah terbentuk. Selain itu, terdapat atheoretical di lapangan, dan tidak secara utama menjadi concern dengan implementasi namun lebih kepada interaksi kesepahaman antar aktor, bukan sektor sasaran. Seperti pada penegakan hukum Nomor 32 Tahun 2009 tentang Perlindungan dan Pengelolaan Lingkungan Hidup, adalah tentang kriteria perbaikan kerusakan ekosistem lingkungan dan perubahan iklim. salah satu dari perlindungan ekosistem mangrove dan Peraturan Daerah (PERDA) No. 14/2007 tentang Ketetanggaan Pulau Bintan dan perencanaan wilayah pesisir.

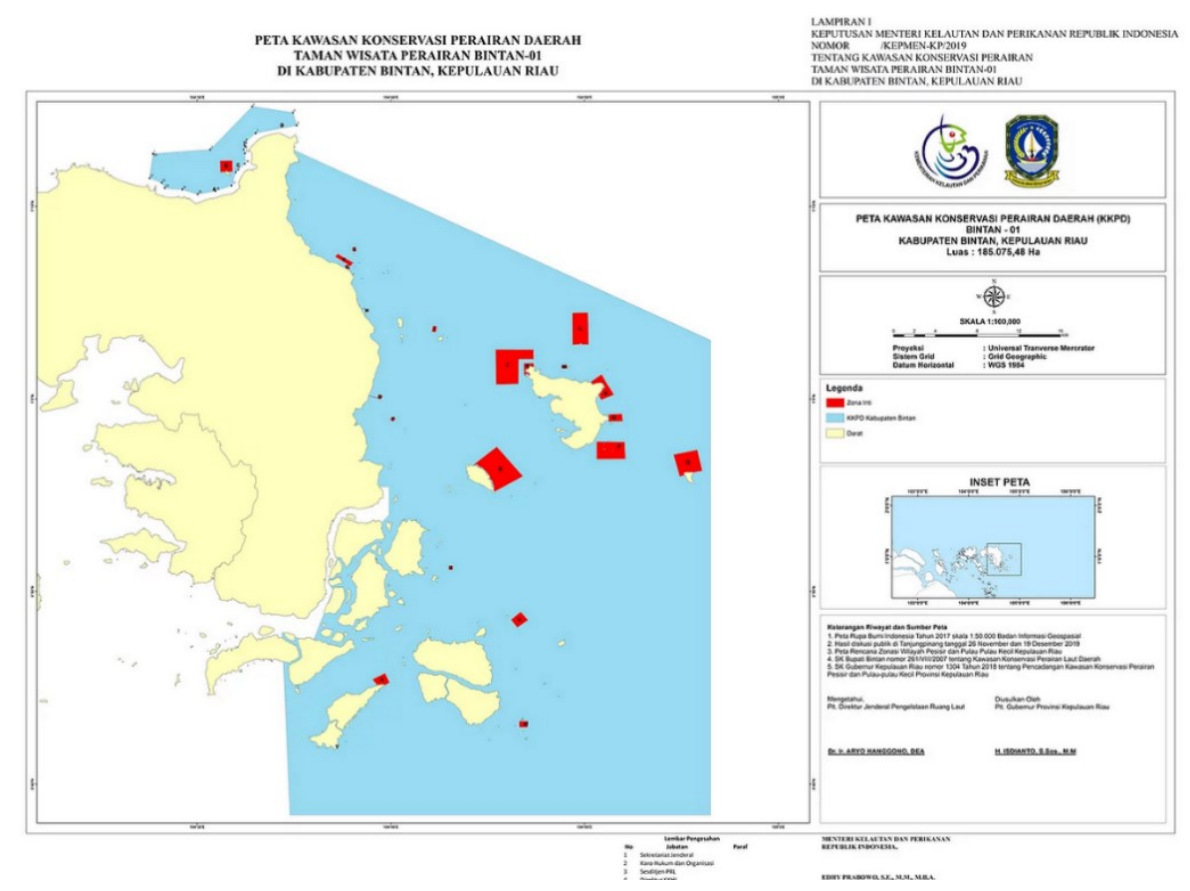

Gambar 5. Kawasan Konservasi Daerah Perairan Bintan Sumber : KKPD Bintan 2021

Membangun keberlanjutan dan mata pencaharian alternatif untuk komunitas masyarakat yang ketergantungan terhadap mangrove. Seperti pada Sulawesi Utara yang mengalihkan Mangrove ke bambu sebagai bahan untuk konstruksi bangunan. Penelitian dan praktisioner harus melihat bahwa kerangka tata kelola dan manajemen harus dikembangkan seiring dengan resiliensi terhadap sosial dan juga ekologi. (Mcleod \& Salm, 2006). Menurut Mongabay, salah satu faktor pemusnah massal Hutan mangrove di Bintan karena penambangan bauksit ilegal yang merusak hektar hutan lindung yang terletak di Pulau Beton, Pulau Elong, dan Pulau Koyang. Perkembangannya juga secara langsung melintasi kawasan hutan mangrove lindung dengan luas hektar. Kepualauan Provinsi Riau ironisnya merupakan provinsi pertama yang dipilih untuk direhabilitasi oleh BRGM (Badan Restorasi Gambut dan Mangrove/ Badan Restorasi Gambut dan Mangrove). (Akbar et al., 2021)

Bagaimana dengan keterlibatan aktor non-state dan keterlibatan organisasi donor internasional untuk membantu dunia ketiga dalam meminimalkan risiko perubahan iklim (Kristanti et al., 2021) dalam berjalannya sebuah rezim internasional? Dalam beberapa pandangan beranggapan bahwa kehadiran dari global civil society sangatlah memiliki tempat di 
mana bermunculan bukti-bukti yang menunjukkan bahwa beberapa aktor non negara memiliki pengaruh tidak hanya pada proses rezimnya, namun juga dalam administrasi dan juga implementasi dalam beberapa forum, bahkan skala global. (Levy et al., 1995). Contohnya dalam pelaksanaan kebijakan restorasi dan rehabilitasi mangrove, diperlukan masyarakat yang telah diedukasi untuk dapat menjaga dan menjamin terlaksananya kebijakan tersebut dan tepat pada sasarannya. Adapun kebijakan terkait program BRGM, dilakukan melalui program padat karya bersama masyarakat lokal sebagai bagian dari civil society di Bintan seperti pada gambar 6 .

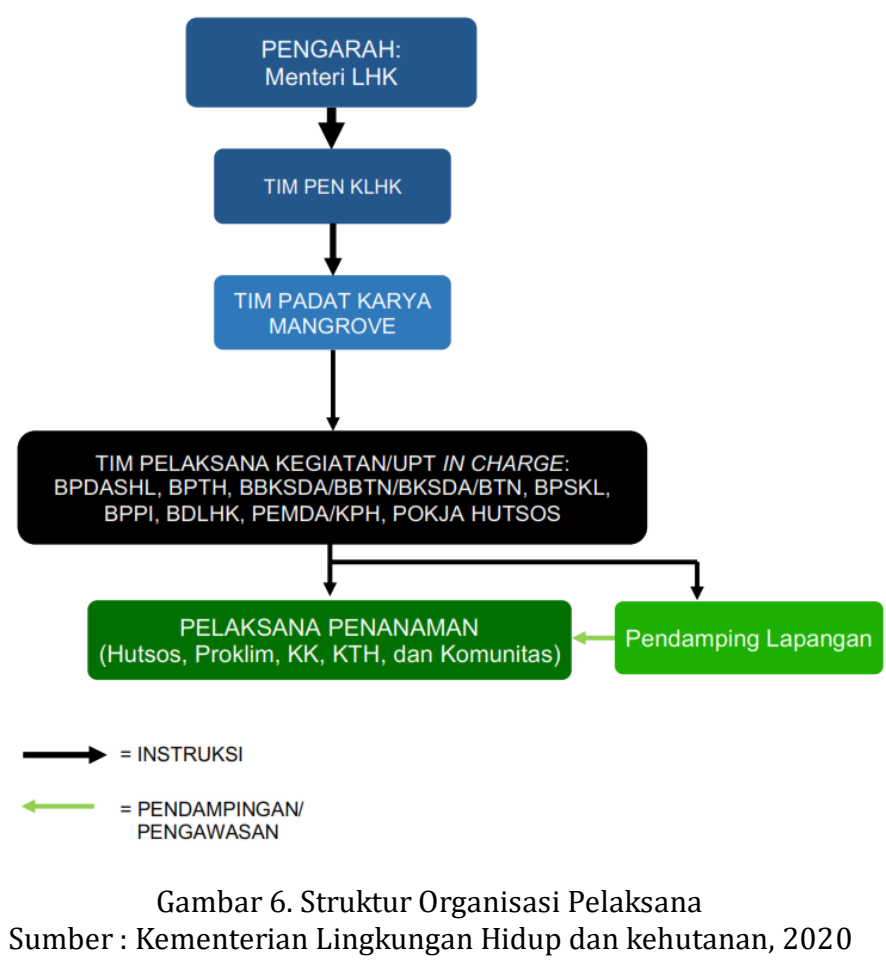

Hutan mangrove hendaknya diprioritaskan, seperti halnya hutan lindung, hutan produksi, dan hutan wisata sesuai dengan potensi ekosistem setempat. Seluruh kebijakan terkait pemanfaatan areal mangrove yang diperuntukkan sebagai kegiatan budidaya harus didukung dengan perundang-undangan yang memadai dengan sektor terkait. Perlu juga dilakukan rehabilitasi terhadap kawasan yang rusak dan memberikan kesempatan itu kepada nelayan dan masyarakat setempat dalam mengolahnya untuk menumbuhkan kesadaran bersama. Berbicara tentang masyarakat lokal, tentu diperlukan adanya pengetahuan dan kesadaran terhadap nilai ekologis, ekonomis dan juga sosial tentang manfaat yang melimpah dari mangrove yang berkelanjutan. (Pramudji, 2011).

\section{KESIMPULAN}

Hutan mangrove hendaknya diprioritaskan, seperti halnya hutan lindung, hutan produksi, dan hutan wisata sesuai dengan potensi ekosistem setempat. Seluruh kebijakan terkait pemanfaatan areal mangrove seperti Rencana Zonasi Wilayah Pesisir dan PulauPulau Kecil (RZWP3K), Rencana Peraturan Daerah Provinsi (RAPENDA), Undang-Undang Nomor 32 Tahun 2009 dan Peraturan Daerah (PERDA) No. 14/2007 yang diperuntukkan sebagai kegiatan budidaya harus didukung dengan perundang-undangan yang memadai dengan sektor terkait. Perlu juga dilakukan rehabilitasi terhadap kawasan yang rusak dan memberikan kesempatan itu kepada nelayan dan masyarakat setempat dalam mengolahnya untuk menumbuhkan kesadaran bersama. Berbicara tentang masyarakat lokal, tentu diperlukan adanya pengetahuan dan kesadaran terhadap nilai ekologis, 
ekonomis dan juga sosial tentang manfaat yang melimpah dari mangrove yang berkelanjutan.

\section{DAFTAR PUSTAKA}

Akbar, D., Irman, Yudiatmaja, W. E., \& Fadli, K. (2021). Managing mangrove forest in Bintan Island: Socio-economic benefits of climate change mitigation and adaptation. IOP Conference Series: Earth and Environmental Science, 724(1). https://doi.org/10.1088/1755$1315 / 724 / 1 / 012103$

Akbar, D, Mariani, Yudiatmaja, W. E., \& Edison. (2021). Governance of mangrove restoration and conservation to climate change resilience in Bintan Island. IOP Conference Series: Earth and Environmental Science, 824(1), 012048. https://doi.org/10.1088/17551315/824/1/012048

Akbar, Dhani, Setiawan, A., Prayuda, R., Putra, A., Aznor, A., \& Yudiatmaja, W. E. (2020). Community Preparedness on Transboundary Oil Spill Governance in Bintan Island. Journal of Physics: Conference Series, 1655(1). https://doi.org/10.1088/17426596/1655/1/012144

Andresen, S. (1995). IlASA. June.

Giesen et al. (2006). Mangrove Guidebook Forsoutheastasia.

Ikenberry, G. J., \& Wendt, A. (1999). Social Theory of International Politics. Foreign Affairs, 78(6), 142. https://doi.org/10.2307/20049552

KEMENLHK. (2020). KepmenLHK tentang Rencana Operasional Padat Karya Penanaman Mangrove.

Kristanti, D., Yudiatmaja, W. E., Rezeki, S. R. I., Yudithia, Samnuzulsari, T., Suyito, Safitri, D. P., \& Akbar, D. (2021). Network governance in addressing climate change: a case study of the Asian Cities Climate Change Resilience Network (ACCCRN) in Indonesia. IOP Conference Series: Earth and Environmental Science, 724(1), 012091. https://doi.org/10.1088/17551315/724/1/012091

Levy, M. A., Young, O. R., \& Zürn, M. (1995). The Study of International Regimes. European Journal of International Relations, 267-330. https://doi.org/10.1177/1354066195001003001

Mcleod, E., \& Salm, R. V. (2006). Managing Mangroves for Resilience to Climate Change. In Science (Vol. 64pp, Issue 2). https://doi.org/10.1017/CB09781107415324.004

Patil, P. G., Virdin, J., Diez, S. M., Roberts, J., \& Singh, A. (2016). Toward a blue econo my: a promise for sustainable growth in the Caribbean. An Overview. The World Bank, 92. http://documents.worldbank.org/curated/en/965641473449861013/pdf/AUS16344REVISED-v1-BlueEconomy-FullReport-Oct3.pdf

Pramudji. (2011). Hutan Mangrove Di Indonesia: Peranan Permasalahan Dan Pengelolaannya. Oseana, 25(1), 13-20.

Setijawati, V. W. (2017). Reclaiming Jakarta's Noth Coast: Perspectives from the Defence, Security, and Constitutional Aspects. Jurnal Hukum Dan Pembangunan, 47(2), 225-238.

Tan, K. H. (2007). Mangrove Plant Diversity in Southeast and East Asia. UNEP/GEF SCS Project Training Course on Sustainable Mangrove Management, May.

Wolinsky, D. F. S., \& Yael. (2020). Cases, Numbers, Models: International Relations Research Methods. Study on International Politics, November, 87-124. https://doi.org/10.1142/9789811214042_0003

Yudiatmaja, W. E., Yudithia, Samnuzulsari, T., Suyito, \& Edison. (2020). Social capital of local communities in the water resources management: An insight from Kepulauan Riau. IOP Conference Series: Materials Science and Engineering, 771(1). https://doi.org/10.1088/1757-899X/771/1/012067 